\title{
SOCIAL INEQUALITY, POWERTY, AND SPATIAL POLARIZATION: EXAMPLE OF HELMIAZIV STREETS
}

\author{
Tetyana ROMANCHENKO \\ Taras Shevchenko National University of Kyiv, Ukraine \\ teromanchenko@gmail.com
}

\begin{abstract}
It is possible to observe the development of social inequality and spatial polarization at the household level within one rural locality. Spatial transformations at the level of the village streets are created by the locals in their own backyards and houses. Internal emotions and people's perceptions of well-being are the drivers of changes. Polarization of social and geographical space are caused by internal beliefs about wealth, prestige, and quality of life.
\end{abstract}

Key words: poverty, welfare, household, population, village.

UDC: 911.3

\section{СОЦІАЛЬНА НЕРІВНІСТЬ, БІДНІСТЬ І ПОЛЯРИЗАЦІЯ ПРОСТОРУ НА ПРИКЛАДІ ВУЛИЦЬ В СЕЛІ ГЕЛЬМЯЗІВ}

\author{
Тетяна РОМАНЧЕНКО \\ Київський національний університет імені Тараса Шевченка, Україна \\ teromanchenko@gmail.com
}

\begin{abstract}
Анотація: На рівні домогосподарств одного сільського населеного пункту можна спостерігати процеси формування соціальної нерівності і поляризації простору. Просторові трансформації на рівні вулиць в селі здійснюються руками мешканців на їх власних присадибних ділянках і будинках. Рушійними силами змін $\epsilon$ внутрішні емоції та уявлення людей про благополуччя. Поляризація суспільного і географічного простору викликана внутрішніми уявленнями про добробут, престижність та якість життя.
\end{abstract}

Ключові слова: бідність, заможність, домогосподарства, населення, село.

удк: 911.3

Актуальність і ціль роботи. Актуальним в світі є новий підхід до виявлення і оцінки бідності, що грунтується не тільки на вартісних підходах, а на суб'єктивному благополуччі населення. В країнах Європи урбаністи вивчають функціональність та сприйняття мікропростору населенням на прикладі вулиць і публічних просторів. На прикладі країн Латинської Америки та Центральної Азії проводяться опитування по сприйняттю життя i щастя. Одним 3 результатів таких досліджень стало виявлення парадоксу «...щасливих селян i нещасливих мільйонерів» (The Paradox of Happy Peasants and Unhappy Millionaires). Відхід від монетарних методів оцінки добробуту населення важливий $з$ тих позицій, що людині для досягнення благополуччя, потрібне почуття самодостатності, позитивний емоційний баланс та відчуття щастя, радощів, прагнення усвідомлення цінності свого життя. Усвідомлення цінності свого життя та ціннісне відношення до нього - це відродження культурних традицій та індивідуальності людини, самобутності народу, формування ідентичності. На рівні села при дослідженні були виявлені соціальні диспропорції, що проявляються в прагненні людини «жити не гірше інших», або «жити, як всі». Соціальна нерівність і бідність має, як зовнішні чинники (загальний розвиток регіону), так i внутрішні (сприйняття людиною себе, як бідною чи заможною).

(C) Т. Романченко
Ціль роботи - виявлення культурних особливостей помешкань жителів села та пояснення з точки зору місцевої специфіки, хто є бідним, а хто багатим в селі. Як в кожному регіоні, місті, районі чи поселенні є своя градація бідних і заможних, своя поляризація соціального і географічного простору, так і в с. Гельмязів є свої місцеві особливості сприйняття достатку.

Огляд літератури по темі. Досить багато вчених визначають бідність як «соціально-економічне й соціокультурне явище, що відображає стан буття населення» [9]. При економічних підходах бідність ототожнюється з відсутністю доходів (дохід визначає матеріальний рівень достатку). 3 таких позицій були обгрунтовані поняття мінімального споживчого бюджету, межі бідності, прожиткового мінімуму. Соціологічне трактування бідності розглядає iï не лише як економічний і соціально-культурний стан груп населення, при яких вони не мають доступу до певних благ, а й особливий спосіб і стиль життя, норми поведінки, стереотипи сприйняття та психології, що передаються із покоління в покоління [11].

В межах суспільної географії категорія «бідність» була розглянута i обгрунтована Н.Гаєвською: «масштабна бідність населення явище, яке заважає формуванню в суспільстві середнього класу, який в свою чергу виступає головним регулятором загального соціальноекономічного прогресу i сталого позитивного 
розвитку держави, стримує їі економічний розвиток, негативно позначається на характері демографічних процесів» [9].

Вивченням структури бідності за групами ризику та визначеннями критеріїв i кількісних оцінок займалися різні вчені - В.І.Добренькова, І.Ф.Гнібеденко, А.М.Колота, А.І.Кравченко, Е.М.Лібанова, В.О.Мандибура, С.В.Мельник, А.І.Мігранова, Т.В.Новікова, Л.Н. Овчарова, Е. А. Ольшанська, Н. М. Рімашевська, М.П. Соколик, А.Ю.Шевякова та ін. Серед наявних географічних досліджень варті уваги роботи таких фахівців, як Т. Ю.Богомолової, . І.Думової, Н.В.Зубаревич, Є.О.Лаптєвої, І.Г.Мельник, В.С. Тапіліної, О. О. Черкашиної, О. У. Хомри, Н. С. Гаєвської.

Західні погляди на бідність відрізняються тим, що при дослідженні бідності до уваги беруться показники суб'єктивного благополуччя на основі опитувань респондентів: «Would people choose what they think would maximize their subjective well-being (SWB)? We present survey respondents with hypothetical scenarios and elicit both choice and predicted SWB rankings of two alternatives. While choice and predicted SWB rankings usually coincide in our data, we find systematic reversals. We identify factors-such as predicted sense of purpose, control over one's life, family happiness, and social status - that help explain hypothetical choice controlling for predicted SWB...» [1]. При таких підходах враховуються доходи європейців та особисте сприйняття їх людиною, що порівнює свій добробут 3 добробутом друзів. Виділяються групи людей по сприйняттю доходів і зазначається, що характер формування таких груп є ендогеним [2]. В період з 1984 по 2000 рр. в Німеччині було проведено дослідження, що стосувалося звикання людей до певного доходу і статусу. Адаптуючись до доходів i звикаючи до певного статусу, викликаного цими доходами, людина почуває себе більш щасливою, коли вони зростають 3 періодичністю в 4-5 років [6]. Спостерігається неухильний інтерес економістів до різноманітних досліджень щастя людини. Ними вважається, що емпіричні дослідження суб'єктивного благополуччя і відчуття індивідуальної корисності можуть дати важливі відомості для економіки. Досліджується, як зміни доходів, безробіття та інфляція впливають на щастя, а також зокрема, як тип демократії і ступінь децентралізації державного правління впливають на задоволення індивідом його життя. Виявляються наслідки економічної політики на життя людей [7]. Carol Graham виявляє також парадокс щасливих селян i нещасливих мільйонерів, поглиблено досліджуючи сприйняття життя і щастя в різних країнах і регіонах, в тому числі і в Центральній Азї та Афганістані, проводячи інтерв'ю (які, до речі, ніколи не публікуються). Нею отримані дані за результатами опитування в Латинській Америці, які показують, як різний стан здоров'я впливає на задоволення здоров'ям і життям людей в різних соціально-економічних групах в різних країнах [8]. Недавно при дослідженнях сприйняття добробуту почали розрізняти два аспекти суб’єктивного благополуччя. Емоційне благополуч- чя відноситься до емоційної якості повсякденного досвіду - частоти інтенсивності переживань радості, стресу, суму, гніву, прихильності, що зробить життя людини приємним чи неприємним. Оцінка життя спрямовується до думки людини, на те, що вона думає про своє життя, коли умисно задумується. Окремо для двох аспектів благополуччя піднімається питання, чи можна купити щастя за гроші. При дослідженні брались до уваги відповіді більше ніж 450000 респондентів на індекс благополуччя. Щодня Організацією Геллапа опитувалося 1000 жителів США. Виявлено, що емоційне благополуччя (вимірюється емоційними переживаннями вчора) та оцінка сприйняття життя (вимірюється за шкалою Кентріла) мають різні кореляти. Доходи і освіта більш тісно пов'язані з оцінкою життя, але здоров'я, увага, догляд, самотність і паління є провісниками щоденних емоцій. При зростанні доходу неухильно зростає оцінка життя. Зростає і емоційне благополуччя, але лише до межі \$75000 на рік, далі нема ніякого прогресу. Низький дохід посилює емоційний біль, пов'язаний з такими явищами, як розлучення, погане здоров’я і самотність. Слідують висновки, що високий дохід може задовольнити життєві потреби, але не дає щастя. Водночас низький дохід провокує низьку оцінку життя і низьке емоційне благополуччя [10].

А. Дітоном удосконалено методику дослідження домогосподарств на економічне зростання. Його методика дає змогу досліджувати стан добробуту населення в різних країнах, опираючись не тільки на доходи та витрати домогосподарств, а й на стан здоров'я, дитячу смертність і емоційний досвід. Дані за цими параметрами зібрано зі 146 країн, більшість яких раніше не були описані. Це призвело нині до багатьох новихідейпророзвитоккраїн обох соціальноекономічних полюсів - заможних і бідних [3]. Також А. Дітон опирається на дані телефонного опитування 340,847 людей в США в 2008 році, де досліджувалась залежність психологічного благополуччя від вікової категорії людини [12]. В своїх роботах А.Дітон критично ставиться до нормативних документів про норми споживання калорій на душу населення та оцінки бідності згідно їх, зазначаючи, що це - «... the charge of miscalculations in the original paper is incorrect, and reflects a misunderstanding of what was done.» [5]. Бідність та нерівність у світі, що визначається паритетом купівельної спроможності i індексу цін в рамках Міжнародного проекту (International Comparison Project), зросла. Це знизило нижню межу бідності по відношенню до американського долара. Проте, А.Дітон зазначає, збільшення бідних людей майже на півмільярда пояснюється неналежною подачею інформації, а не зміною купівельної спроможності. При порівнянні достатку різних країн даються взнаки слабкі теоретичні та емпіричні основи [4].

\section{Виклад основного матеріалу.}

Для детальної оцінки сучасного стану всіх будинків була введена п’ятибальна шкала оцінювання. Вона відображає господарський стан домогосподарства і роль його власника в суспільному житті. Так, за рівнем і достатком життя ми виділили 
п’ять окремих категорій домогосподарств:

- Злиденні - часто покинуті і занедбані домогосподарства. Житлові приміщення перебувають в напівзруйнованому стані. Будинки запущені, в них відсутнє опалення і водопостачання. Подвір'я засмічене, неприбране. Якщо в такому будинку довго ніхто не проживав, то він досить часто служить тимчасовим притулком для місцевих наркоманів, негативно спрямованої молоді і залежних від алкоголю осіб. Якщо в таких домогосподарствах живуть люди, то часто вони $є$ виключенням із нормального суспільного життя, адже їм не вистачає знань, вмінь і коштів підтримувати усталений спосіб життя в даній місцевості і тримати здоровий діалог із оточенням.

- Незаможні - господарська діяльність наявна, але не в повній мірі. Господарі не грають ключової ролі в суспільному житті. Ця група незаможних осіб відрізняється від попередньої тим, що з нею можливий діалог і контакт. Це люди, яким не вистачає умінь і навичок виживати в сучасному поляризовану світі через вікові, освітні чи фізіологічні особливості.

- Відносно-заможні - група домогосподарств, які за кількісним переважанням відображають сільську місцевість в цілому. Сюди належить більшість домогосподарств, власники яких є хорошими господарями, які за умов низьких державних доходів вміють підтримувати свою присадибну ділянку в гарному вигляді. Це особи, які займають основні соціальні позиції: лікарі, вчителі, юристи, бухгалтери, бібліотекари, вихователі, сторожі, пекарі тощо. За їхніх ініціатив проводяться основні заходи в селі. Між представниками цієї групи існують досить стійкі зв'язки: трудові, культурні, виробничі тощо. Люди гуртуються між собою, спілкуються i утворюють громаду. 3 радянського періоду у вигляді їхніх домогосподарств не було значних структурних зрушень, але вони виглядають достойно і привабливо за рахунок дбайливого ставлення і підтримання порядку. Для сільської людини дуже важливо мати естетично привабливе подвір'я, адже це характеризує їі як господаря.

Середньо-заможні - такі домогосподарства, які стали краще розвиватися після отримання Україною незалежності. В їхньому інтер'єрі сталися суттєві зміни за період становлення ринкової економіки. Господарі змогли використати ринкові відносини для покращення стану свого господарства. Вони зайнялися прибутковою діяльністю і це їх досить вирізняє від оточуючих. Більшість із них приватні підприємці, що займаються торгівлею та задіяні в сфері послуг.

- Заможні - це домогосподарства-лідери за соціально-економічним розвитком іза своєю сутністю вони $є$ виключенням для сільської місцевості. Належать великим підприємцям або приїжджим особам $з$ міста, що купили земельну ділянку, щоб збудувати дачу [рис. 1, 2].

За періодом економічного піднесення ми виділили три групи домогосподарств:

1. Домогосподарства, що активно розвивалися під час II половини XX ст. Становлення їх пов'язане 3 розбудовою після війни. Економіка в державі була плановою, а господарства - колективними. Будівництво житла було доступним для місцевого населення (діяли цегляні заводи).

2. Домогосподарства, які значно розвинулись після отримання Україною незалежності. До 1990 pp. вони були на рівні з домогосподарствами першої групи, але після розпаду СССР і переходу на ринкові засади господарювання їхніми власниками, загальний вигляд подвір'їв і будинків змінився і продовжує

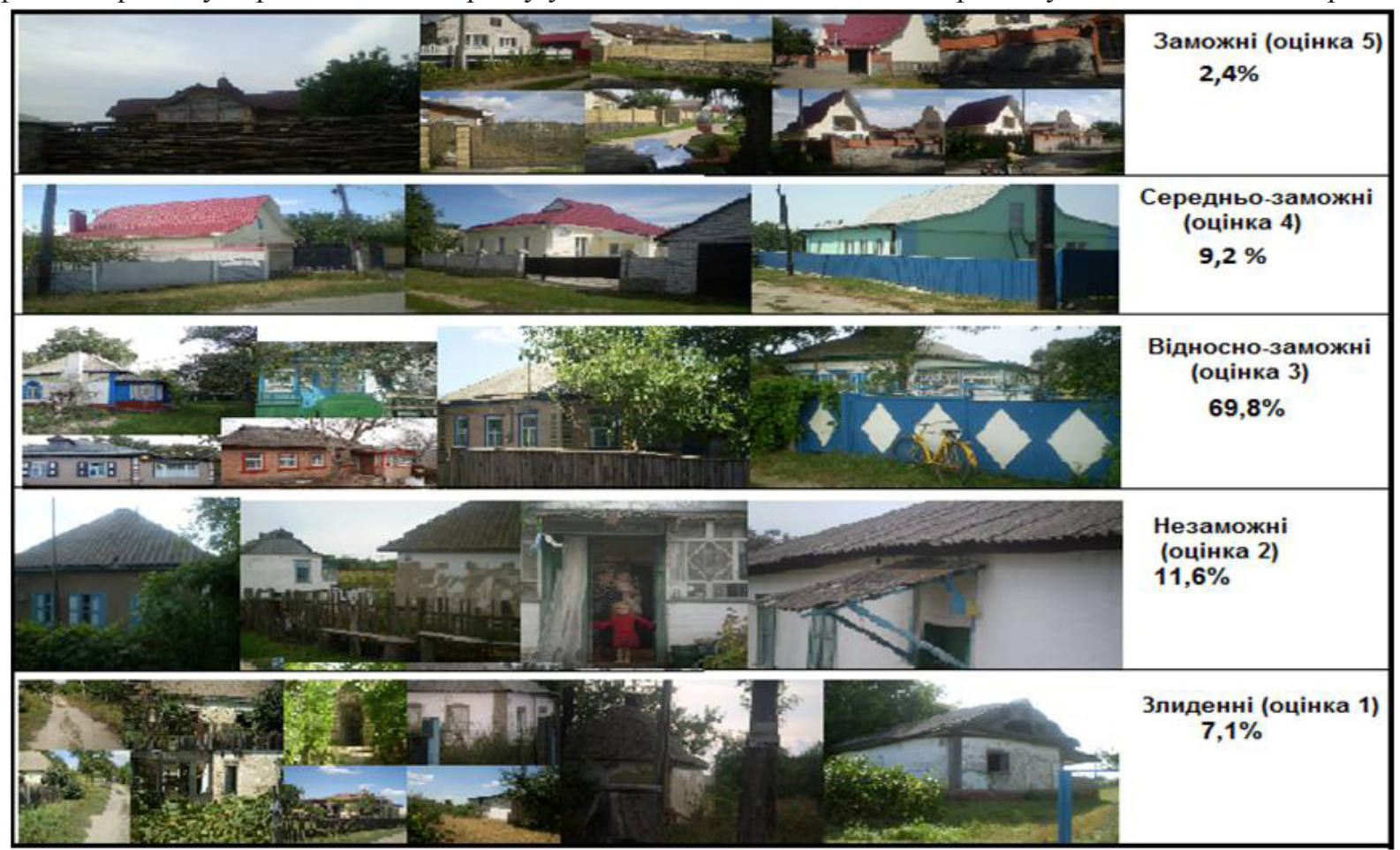

Рис.1. Класифікація будинків за станом бідності / заможності 

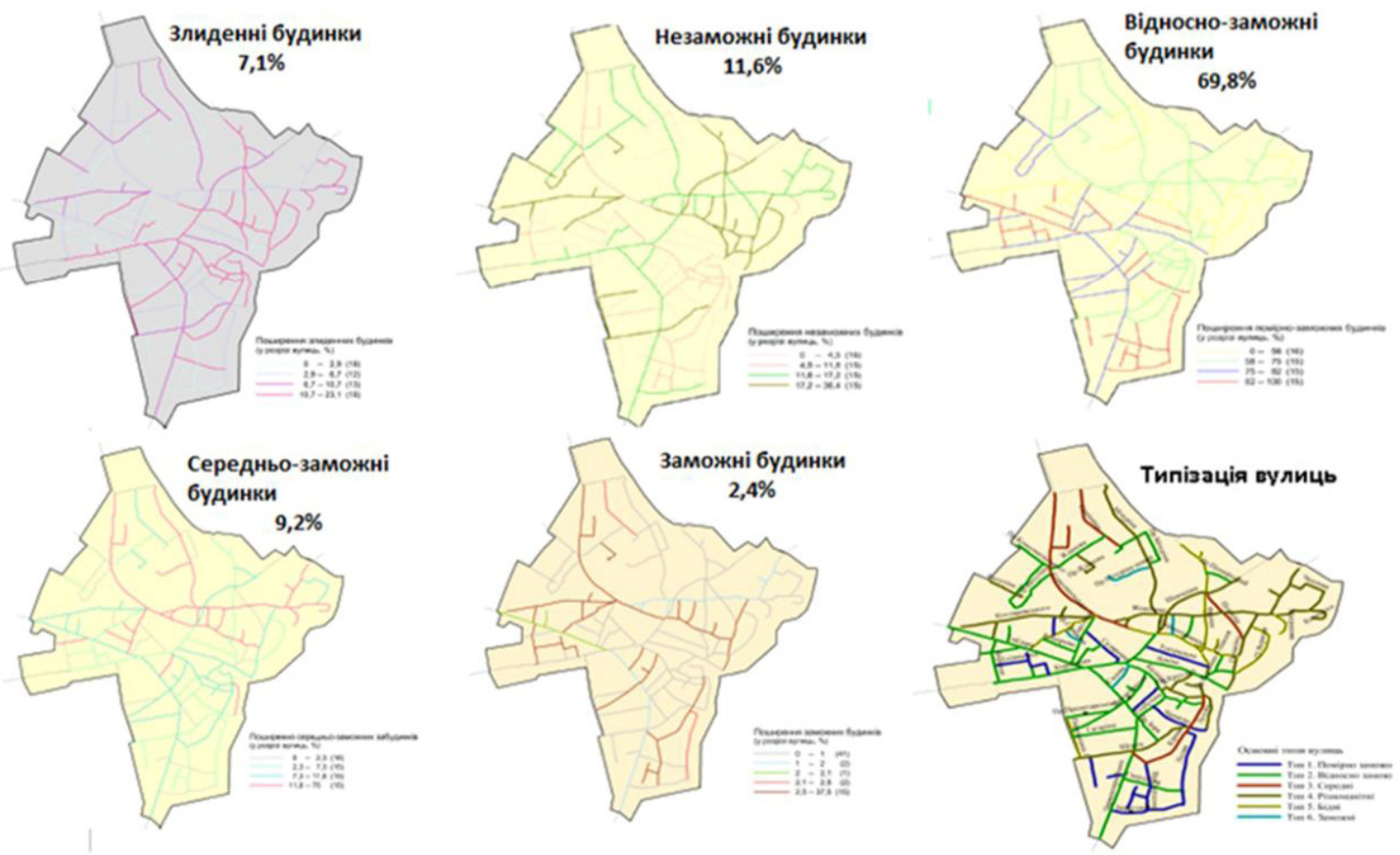

Рис.2. Поширення різних типів будинків на території села Гельмязів

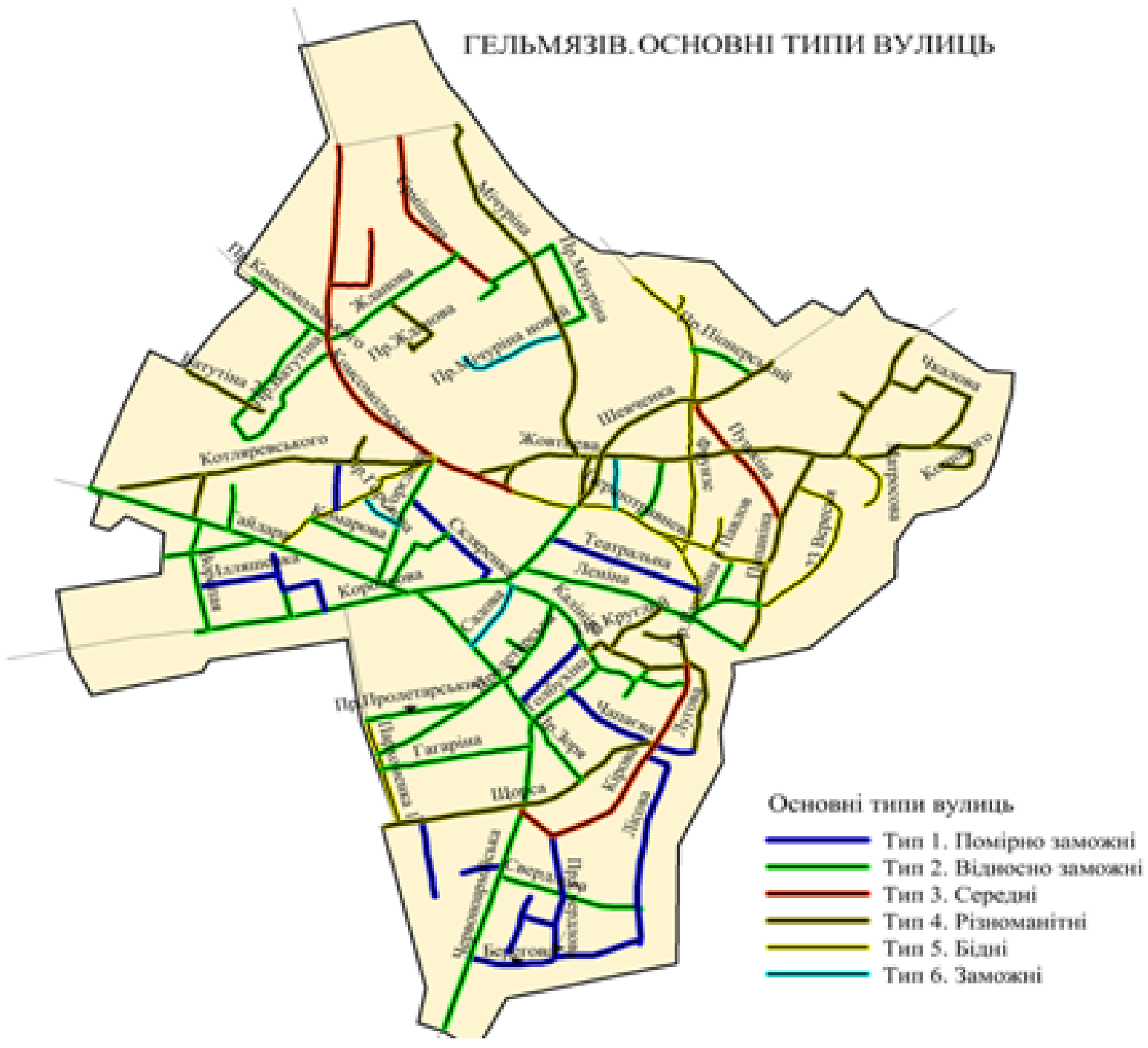

Рис.3. Основні типи вулиць у селі Гельмязів 
змінюватись. В їхньому інтер'єрі є новітні елементи ознаки нового часу, недоступні для інших категорій місцевого населення. Господарі даних будинків зуміли знайти для себе вигідні види економічної діяльності - в сфері послуг, торгівлі, веденні бізнесу тощо на місцевому, локальному рівні, що дозволяє підтримувати їм достойний спосіб життя і поступово покращувати благоустрій.

3. До третьої групи віднесені будинки, що мають застарілі об'єкти господарювання та виглядають дуже бідними. В них основні приміщення напівзруйновані, а подвір'я дуже занедбані. Це будинки, що були збудовані ще до війни, або, можливо, до революції. Але вони не повною мірою розвивались під час радянської повоєнної розбудови. Можливо, на той час вони мали достатній рівень розвитку і не потребували оновлень. Найбільше їх збереглося в старій частині села - в історичному ядрі.

На основі обрахунків зібраних показників була здійснена типізація вулиць, з урахуванням основних територіальних відмін у їхньому розвитку.

Основні типи вулиць [рис 3]:

Тип 1. «Помірно заможні» - До даного типу належить 18\% вулиць: Чапаєва, Пархоменка (2), пр. Червоноармійський, пр. Свердлова, Театральна, Скляренка, пр. Котляревського, Ілляшенка, Лісова, пр. Червоний та Берегова. Головною ознакою цього типу є значна частка відносно-заможних будинків (в середньому 89,9\%), що належать до першого періоду економічного піднесення $(96 \%), 3$ переважанням дерев'яних $(54,1 \%)$, залізних $(17,4 \%)$ та наявністю євро-огорож $(15,7 \%)$.

Тип 2. «Відносно заможні» - Цим типом представлені 38\% вулиць: пр. Першотравневий 2, пр. Піонерський, пр. Папаніна і Павлова, Гагаріна, пр.Пролетарський, Пролетарська, Толбухіна, Червоноармійська, Калініна, Леніна, Корольова, Воропая , Тюленіна, Гайдара, пр. Мічуріна, Жданова, Макаренка - Героя Чорного, Горєлова, Комарова, пр.Ватутіна, пр. Комсомольський, Ватутіна, Свердлова.

Це вулиці з відносно заможними будинками. Рівень відносної заможності сягає від 70 до 85\% та $77 \%$ в середньому, що свідчить про включення незаможних (10,5\%) та злиденних $(6,3 \%)$, а також - середньо-заможних (5,3\%) домогосподарств. Це тип вулиць, в якому проявляється ледь помітна зростаюча тенденція до соціально-економічного контрасту. Спостерігається переважання першого (89,5\%) або другого в поєднанні 3 третім, (8,5\%) періоду економічного піднесення. В межах вулиць переважають дерев'яні огорожі (40\%) 3 помітною часткою інших

Тип 3. «Середні» - Даного типу вулиць ідентифіковано 6,6\%. Це Пушкіна, Кірова, Комсомольська, Єрмішина. Вони характеризуються середнім показником заможності $(68,4 \%)$ з помітною тенденцією до збіднення: 9,8\% домогосподарств цих вулиць є незаможними та 10,7\% злиденними. Переважна більшість домогосподарств віднесена до першого періоду економічного піднесення (92,5\%) 3 переважанням дерев'яних огорож, значною часткою інших та великим відсотком $(8,5 \%)$ домогосподарств 3 відсутньою огорожею подвір'я

Тип 4. «Різноманітні» - $\mathrm{B}$ даному типі представлено 20\% вулиць: Шевченка, Папаніна, пр. Круглий, Жовтнева, Мічуріна, Лугова, Котляревського, Ватутіна, пр. Жданова, Щорса, Чкалова, Кошового.

Це вулиці бідних домогосподарств $(17,9 \%)$ та злиденних $(9,4 \%)$. Середній рівень заможності становить 60,6\%. Відносно-заможних домогосподарств тут $10,9 \%$. Останній ілюструє високий рівень розриву між заможними i злиденними, що не $\epsilon$ соціально сприятливим явищем. В данному типі високе значення мають 2 i 3 період економічного піднесення (8,2\% та 7,2\%). Це свідчить про контраст: одночасне розміщення бідних і заможних домогосподарств на одній вулиці, можливо - доглянутих і покинутих. Спостерігається висока частка відсутніх парканів $(8,2 \%)$

Тип 5. Бідні - Вулиць данного типу нараховано 10\% від загальної кількості. Сюди віднесено: Пархоменка, 23 Вересня, Першотравнева, Фрунзе, Гоголя, Матросова. Це бідні вулиці з переважання 2-3 або 3 періоду. Бідність сягає 22,6\%, а злиденність - 17,4\%. Поширені в найбільшій мірі дерев'яні паркани, але досить велика частка домогосподарств парканів не має (11,5\%). Представлені в достатній кількості і середньо-заможні домогосподарства. Це також тип соціальних розривів і нерівностей.

Тип 6. Заможні - Вулиць цього типу виявлено 6,6\%. А саме: пр. Горєлова, пр. Мічуріна, пр. Новий, пр. Першотравневий, Садова. Найбільш неоднорідна й контрастна по відношенню до інших група вулиць. В ній надзвичайно високі показники абсолютної заможності (максимальне значення - 37,5\% та середнє - 18,3). Відносна заможність за абсолютним показником становить $75 \%$ та в середньому $46,1 \%$. Водночас наявні і бідні домогосподарства: максимальне значення становить $14,3 \%$, середнє $6,7 \%$. Вулиці даного типу дуже слабко представлені відносно-заможними домогосподарствами. Переважає другий період економічного піднесення. Третій період не представлений взагалі. Переважають паркани з європрофілю та кам'яно-бетонні.

\section{Висновки}

Визначено, що бідними є вулиці, що розміщені в історичному ядрі. Бідність, як явище тут почало формуватися давно і пов'язане 3 розвитком інших територій села. Коли ресурси по будівництву i відновленню інфраструктури були перекинуті на інші частини села (південна, центральна і західна) ще в радянські часи, то там були сформовані кращі і вигідніші умови для розвитку домашнього господарства.

Північна частина села відзначається недавнім розвитком, а східна - деякою відсталістю, тому на північному сході спостерігається значний соціальноекономічний контраст розвитку території: одночасне розміщення дуже бідних і заможних господарств.

Водночас, якщо сучасний розвиток і спровокував погіршення стану деяких домогосподарств 
на вузьких периферійних вулицях, то водночас він викликав i пожвавлення господарського життя в інших частинах села. Отже, бідність у сільській місцевості все ж таки можна подолати шляхом переосмисленням відносних цінностей щодо зовнішнього вигляду домогосподарств та переорієнтацією людей на комплексну соціальну активність. Подолання бідності в сільській місцевості - це подолання депресивного світосприйняття і орієнтація на створення соціальних цінностей.

\section{References:}

1. Benjamin D., Hegetz O., Kimball M., Rees-Jones A. What Do You Think Would Make You Happier? What Do You Think You Would Choose? American Economic Review, 2012, Vol. 102, pp. 2083-2110.

2. Clark A., Senik C. Who Compares to Whom? The Anatomy of Income Comparisons in Europe. Economic Journal, 2010, Vol. 120, pp. 573-594.

3. Deaton A. Measuring Development: Different Data, Different Conclusions? In: Measure for Measure: How Well Do We Manage Development, 2010.

4. Deaton A. Price Indexes, Inequality, and the Measurement of World Poverty. American Economic Review, 2010, Vol. 100 (1), pp. 5-34.

5. Deaton A., Dréze J. Nutrition, Poverty and Calorie Fundamentalism: Response to Utsa Patnaik. Economic and Political Weekly, 2010, Vol. 45 (14), pp. 78-80.

6. Di Tella R., Haisken-De New J., MacCulloch R. Happiness Adaptation to Income and to Status in an Individual Panel. Journal of Economic Behavior and Organization, 2010, Vol. 76, pp. 834-852.

7. Frey B., Stutzer A. What Can Economists Learn from Happiness Research? Journal of Economic Literature, 2002, Vol. 40, pp. 402-435.

8. Graham C. Happiness Around the World: The Paradox of Happy Peasants and Unhappy Millionaires. Oxford University Press, 2012.

9. İŝuk S.Ì., Gaêvs'ka N.S. Mel'nik Ì.G. Bìdnìst', âk socìal'no-ekonomična kategorîâ j ob'êkt doslìdžennâ suspìl'noï geografiï [Poverty: socio-economic category and subject for human geography]. Ekonomična ta socìal'na geografîa [Economic and social geography], 2011, Vol. 62, pp. 56-64. (In Ukrainian).

10. Kahneman D., Deaton A. High Income Improves Evaluation of Life but Not Emotional Well-Being. Proceedings of the National Academy of Sciences, 2010, Vol. 107(38), pp. 16489-16493.

11. Sociologičeskaâ ènciklopediâ [Sociological Encyclopedia]. General Editorship: A. N. Danilova. Minsk, 2003, 384 p. (In Russian).

12. Stone A., Schwartz J., Broderick J., Deaton A. A Snapshot of the Age of Distribution of Psychological WellBeing in the United States. Proceedings of the National Academy of Sciences, 2010, Vol. 107 (22), pp. 9985-9990. 